Журнал«Герспективита інновації наукиљ

(Серія«Гедагогіка», Серія«ГЕихологія», Серія«Медицина»

№4(4) 2021

УДК 159.9.019

https://doi.org/10.52058/2786-4952 -2021-4(4)-330-340

Василець Катерина Віталіївна $\mathrm{PhD}$ здобувач Інституту соціальної та політичної психології, вул. Андріївська, 15, м. Київ, 04070, тел.: (093) 268-89-14, e-mail: k.v.vasilets@gmail.com, https://orcid.org/0000-0002-6670-089X

\title{
НАУКОВІ ПОГЛЯДИ ТА СУЧАСНИЙ СТАН ДОСЛІДЖЕННЯ ОПАНОВУВАЛЬНОЇ ПОВЕДІНКИ
}

Анотація. У статті висвітлено результати теоретичного аналізу наукового доробку вітчизняних та зарубіжних представників щодо вивчення опанувальної поведінки. Протягом життя людині доводиться опановувати безліч складних ситуацій. Швидкі темпи технологічного розвитку, суспільні зміни та нестабільність різних сфер суспільства призводять до зниження психологічної стійкості особистості до негативних впливів. Зазначені фактори спричиняють постійну актуальність дослідження опановувальної поведінки.

Опановувальна поведінка розглядається нами як сукупність зусиль, які дозволяють їй впоратися зі складними життєвими ситуаціями та забезпечують продуктивність, здоров'я і благополуччя людини. Теоретичний аналіз наукових робіт присвячених дослідженню цього феномену дав можливість окреслити особливості опанувальної поведінки та основні розбіжності у поглядах науковців стосовно цього феномену. Було встановлено, що у більшості досліджень механізми психологічного захисту та копінг-стратегії розглядаються в тісній взаємодії в системі опанування. Механізми психологічного захисту функціонують поза межами свідомості та дають можливість швидкого зниження емоційної напруги, проте надлишкове включення їх у процеси опанування позбавляє особистість об'єктивно оцінювати ситуацію. Копінг-стратегії є усвідомленими процесами, що можуть піддаватися контролю. Взаємодія зазначених феноменів робить процес опанування складних ситуацій більш ефективним.

Аналіз наявного науково доробку також дав можливість встановити, що на сьогодні аспект взаємозв'язку моральної сфери особистості та опанувальної поведінки мало досліджений, а тому потребує більш детального вивчення, адже моральна сфера виступає регулятором поведінки людини. Окреслено перспективи подальших розвідок у дослідженні особливостей опановувальної поведінки осіб з різними типами моральної свідомості.

Ключові слова: опановувальна поведінка, копінг-стратегії, механізми психологічного захисту, копінг, опанування.

Vasylets Kateryna Vitaliivna $\mathrm{PhD}$ student of the Institute of Social and Political Psychology, Andriivska St., 15, Kyiv, tel.: (093) 268-89-14, e-mail: k.v.vasilets@gmail.com, https://orcid.org/0000-0002-6670-089X 


\section{SCIENTIFIC VIEWS AND CURRENT STATE OF RESEARCH}

Abstract. The article highlights the scientific theoretical achievements analysis results of domestic and foreign representatives in the mastering behavior study. During life a person has to master many difficult situations. Rapid pace of technological development, social change and instability in various society spheres lead to a decrease in the psychological individual resilience to negative influences. These factors cause the constant relevance of the mastering behavior study.

Mastery behavior is considered by us as a set of efforts that allow it to cope with difficult life situations and ensure productivity, health and well-being. Theoretical analysis of scientific works devoted to the study of this phenomenon made it possible to outline the mastering behavior features and the main differences in the scientists views on this phenomenon. It was ascertained that in most studies, the psychological protection mechanisms and coping strategies are considered in close cooperation in the mastering system.

The psychological protection mechanisms function outside the consciousness and allow a rapid emotional stress reduction, but their excessive inclusion in the processes of mastery deprives the individual to objectively assess the situation. Coping strategies are conscious processes that can be controlled. The phenomena interaction makes the process of mastering complex situations more effective.

The available scientific achievements analysis also made it possible to establish that today the relationship aspect between the moral personality sphere and mastery behavior is little studied, and therefore requires more detailed study, because the moral sphere is a human behavior regulator. Prospects for further explorations in the peculiarities of mastering persons behavior study with different moral consciousness are outlined types.

Keywords: mastering behavior, coping strategies, mechanisms of psychological protection, coping, mastering

Постановка проблеми. Однією з основних соціальних проблем сучасного суспільства $є$ проблема психологічного стресу, що призводить до погіршення загального функціонального стану суспільства: зниження рівня адаптації, погіршення професійної ефективності та розвиток психосоматичних хвороб. Протягом життя людина неминуче стикається з необхідністю вирішення проблем різного роду, адже життя пронизане складними ситуаціями, які пов'язані 3 вибором адекватного способу вирішення різних життєвих труднощів, психологічних проблем та подолання кризових станів. Останнім часом спостерігається суттєве збільшення агресивно насиченої інформації, висока нестабільність соціальної, політичної та економічної сфери суспільства та як наслідок знижується психологічна стійкість особистості до деструктивних впливів. Такі умови висувають потребу у підвищенні адаптаційних можливостей людини, тому що благополуччя та загальний стан психологічного здоров'я буде 
Журнал«Герспективита інновації науки

(Серія «Гедагогіка», Серія «Гтихологія», Серія «Медицин»

№4(4) 2021

залежати від можливості подолання стресу. Загалом динамічність і складність життя, його суперечливість ставить нас перед необхідністю постійного вивчення опановувальної поведінки та пошуку морально релевантних способів виходу зі складних ситуацій і конфліктів, а також особистісних та професійних криз.

Аналіз останніх досліджень 3 проблеми. Дослідження опанувальної поведінки не втрачають своєї актуальності, свідченням цього є велика кількість робіт присвячених цій проблематики. Більшість авторів розглядають опановувальну поведінку як поведінку, в якій основною складовою є копінгстратегії (Р. Грановська [8], I Корнієнко [15], Р. Лазарус [11], I. Нікольська [8] та ін.). Також у науковій літературі представлені погляди вчених, які значну увагу у структурі опановувальної поведінки надають механізмам психологічного захисту (Ф. Бассін [3], А. Налчаджян [4] та ін.).

Метою статті $є$ розкриття та аналіз наукових поглядів щодо феномену опановувальної поведінки та їі складових.

Виклад основного матеріалу. Під опановувальною поведінкою ми розуміємо сукупність зусиль людини, які дозволяють їй впоратися зі складними життєвими ситуаціями та забезпечують продуктивність, здоров'я і благополуччя людини.

Основою нашого розуміння опановувальної поведінки стали погляди науковців щодо проблеми дослідження копінг-статегій та механізмів психологічного захисту. На нашу думку, для глибшого розуміння опанувальної поведінки необхідне дослідження зазначених вище феноменів у тісному взаємозв’ язку.

Сучасне трактування механізму психологічного захисту акцентує увагу на тому, що це психологічний процес, який відбувається несвідомо та спрямований на подолання внутрішньої напруги, негативних переживань та збереження психологічного здоров'я людини.

Уявлення про механізми психологічного захисту на початковому етапі формувалися в рамках психоаналізу. 3. Фрейдом природа механізмів психологічного захисту розглядалась в контексті внутрішньоособистістного конфлікту, який відбувається між «Ід» та «Супер-Его». Концепція психологічного захисту у класичному психоаналітичному підході була представлена А. Фрейд у книзі «Его i механізми захисту». Дослідниця характеризувала захисні механізми як «діяльність "Я", яка починається, коли "Я" піддається надзвичайній активності спонукань або афектів, що представляють для нього небезпеку. Вони функціонують автоматично, без узгодженості зі свідомістю» [1, с.62]. Мету функціонування захисних механізмів А. Фрейд пов'язувала 3 обмеженням розвитку тривоги (незадоволення) та перетворення інстинктів, що дозволяє адаптуватися до складних ситуацій [1].

Дослідження природи механізмів психологічного захисту у структурі «Я» особистості представлено у роботах К. Хорні, Е. Фромма. Обидва дослідники наголошували на важливості цілісності «Я» особистості, проте К. Хорні 
функціональні особливості захисних механізмів вбачає не у подоланні конфлікту між особистістю та її оточенням, а у гармонізації сприйняття себе та оточуючих, для уникнення невротичного комплексу (Хорні, 1993).

Подальше дослідження механізмів психологічного захисту відбувалося у рамках різних психологічний шкіл, що дозволяє нам виокремити два протилежних трактування цього феномену. Так у роботах Ф. Бассіна та А. Налчаджян механізми психологічного захисту розглядаються як нормальна реакція та механізм людської свідомості, що $є$ постійно функціонуючим. При цьому Ф. Бассін вказував, що головною функцією психологічного захисту виступає перебудова системи установок, що спрямована на усунення надмірного емоційного напруження [3]. А. Налчаджян, в свою чергу, підтримуючи погляди колеги, наголошує на важливості захисних механізмів у процесі соціальнопсихологічної адаптації особистості [4]. Протилежну думку у своїх роботах висвітлюють Ф. Василюк та Т. Даценко вказуючи, що психологічний захист $\epsilon$ непродуктивним способом вирішення стресової ситуації, який обмежує розвиток особистості та виступає перешкодою для «виходу на новий рівень регулювання та взаємодії зі світом» $[5,6]$.

Вагомий внесок у вивчення психологічних захистів та розробку методів їх тестування зробив Р. Плутчик. Головню ідеєю його трактування механізмів психологічного захисту виступає те, що вони $\epsilon$ «похідними емоцій», а емоції в свою чергу, визначаються як базові засоби адаптації. Крім того, вчений звернув увагу на те, що захисні механізми характеризуються біполярністю так само як і емоції, які лежать в їх основі. Також Р. Плутчиком було представлено вікову послідовність розвитку механізмів психологічного захисту. Автор зазначає, що механізми психологічного захисту $\epsilon$ примітивними неусвідомлюваними методами реагування на стрес чи загрозу, які у дитинстві виступають нормальною реакцією, а у дорослому - негнучкими способами поведінки у стресових ситуаціях. Механізми психологічного захисту у дорослих Р. Плутчик протиставляє копінг-стратегіям, які на думку вченого, є гнучкими та деколи креативними методами вирішення конфліктів чи стресових ситуацій, що мають зв'язок з різного роду негативними емоціями. Переважання у людини певного захисного механізму може призвести до розвитку певних рис та акцентуацій характеру. Певний механізм захисту як засіб викривлення реальності може характеризувати серйозні особистісні розлади. Найбільш грунтовно цей взаємозв'язок представлений в дослідженнях Г. Келлермана та Р. Плутчика, які пропонують специфічну мережу зв'язку між різними рівнями особистості (емоціями, захистом, спадковою схильністю до психічних захворювань) [7].

P. Грановська та I. Нікольська зазначають, що проблема психологічного захисту включає в себе «центральне протиріччя» між прагненням людини зберегти психологічну рівновагу i тими втратами, до яких призводить надлишкове втручання захистів. 3 одного боку, як вказують дослідниці, неможливо заперечити користь усіх видів механізмів психологічного захисту, що 
покликані знижувати накопичену людиною напругу шляхом спотворення висхідної інформації чи відповідної зміни поведінки людини. 3 іншого боку, їх надлишкове включення не дає можливості особистості усвідомити об'єктивну, справжню ситуацію, адекватно та творчо взаємодіяти зі світом [8, с.13].

Українська дослідниця Д. Тітаренко визначає психологічний захист як «психологічну систему регуляції психіки людини, що спрямована на зняття або зменшення тривожності, пов'язаної 3 відчуттям ситуації, що несе в собі екзистенціальну загрозу» [9, с.13]. Підтримуючи погляди попередників, дослідниця вважає, що основою формування психологічного захисту є вродженні здібності, індивідуальні особливості людини та рівень їі індивідуального досвіду. Механізми психологічного захисту в свою чергу впливають на формування моральних установок особистості, іi життєвих поглядів, якостей характеру, стилю поведінки та засвоєння життєвого досвіду. Це пов’язано з тим, що механізми психологічного захисту безпосередньо приймають участь у процесі сприйняття оточуючого світу, вони виступають певною мірою фільтром через який проходить внутрішня та зовнішня інформація, яка поступає до особистості [9, с.15].

Загалом узагальнюючи різні підходи до розуміння природи механізмів психологічного захисту, можна зазначити, що вони являють собою певну психологічну систему, яка спрямована на зниження емоційного напруження, яке може загрожувати збереження цілісності особистості. Зазвичай таке емоційне напруження виникає у результаті суперечностей між сформованим особистістю образом світу, власного «Я» та зовнішньою інформацією [10]. Більшість досліджень механізмів психологічного захисту були проведені клінічними психологами та показали, що кожен вид психологічного захисту надає людині лише відносне відчуття гармонізації внутрішнього психологічного стану та особистого благополуччя. Накопичення людиною невирішених проблем може призводити до неможливості впливати на ситуацію, для подальшого усунення причин негативних переживань. Враховуючи, що психологічні захисти $\epsilon$ модальні, їх можна розглядати як позитивні або негативні процеси. Позитивною стороною психологічних захистів виступає їх спрямованість на подолання негативних емоцій, переживань та тривоги в складних життєвих ситуаціях. Негативною стороною - виступає нетривалість психологічних захистів та спотворення сприйняття реальності для забезпечення емоційної стабільності особистості [9, с.14].

В системі опановувальної поведінки, як вже зазначалося вище, механізми психологічного захисту тісно пов'язані з копінг-стратегіями (копінгами), що виступають свідомими зусиллями людини, які спрямовані на подолання складних ситуацій.

В рамках транзакціональної когнітивної теорії «копінг-механізми» визначаються як стратегії дій, які використовує людина в ситуаціях психологічної загрози фізичному, особистому чи соціальному благополуччю. 
Перша спроба об'єднати копінг-стратегії та захисні механізми в один конструкт була зроблена Р. Лазарусом в рамках дослідження психологічних проблем пристосування особистості до хвороби. При цьому він розглядав копінг-стратегії як активні, гнучкі і конструктивні механізми, протиставляючи їх пасивним, ригідним і дезадаптивним механізмам психологічного захисту. У більш пізніх роботах Р. Лазарус та С. Фолькман визначають поняття «копінг» як діяльність особистості, яка спрямована на підтримку і збереження балансу між вимогами середовища і ресурсами, що задовольняють ці вимоги [11].

Як у дослідженнях механізмів психологічного захисту, у дослідженнях копінг-стратегій («копінг») можна виокремити кілька підходів трактування цього феномену.

Перший з них представлено у роботах Н. Хаан. Дослідниця розглядаючи «копінг» вказує, що це Его-процеси, які сприяють продуктивній адаптації особистості у важких ситуаціях. Особливостями такої поведінка, на думку Н. Хаан, є включення когнітивних, соціальних, мотиваційних та моральних структур особистості у безпосереднє вирішення проблем [12]. Якщо особистість проявляе нездатність до адекватного вирішення проблем, включаються механізми психологічного захисту, які забезпечують пасивну адаптацію. Вони виступають ригідними, дезадаптованими способами вирішення проблем, які створюють перешкоди для адекватної орієнтації індивіда у реальній дійсності. Таке розуміння поєднання копінг-стратегій та механізмів психологічного захисту передбачає, що обидва прояви опановувальної поведінки залучають однакові Его-процеси, які різноспрямовані за модальністю. Варто зазначити, що в контексті цього підходу конструктивна опановувальна поведінка обумовлюється рівнем розвитку копінг-ресурсів, які виступають внутрішніми та зовнішніми резервами, на основі яких людина обирає способи реагування на стрес [13].

У рамках другого підходу поняття «копінг» розглядається як особистісні якості, які дозволяють використовувати відносно постійні варіанти реагування на ситуації викликані стресом. Цей підхід грунтовно представлений у роботах А. Біллінгс та Р. Моос. Загалом дослідники виокремлюють три способи подолання стресових ситуацій: 1) подолання стресу передбачає спроби оцінки значущості ситуації; 2) подолання стресу включає усунення чи зменшення його джерела; 3) подолання стресу передбачає певні зусилля, за рахунок яких людина прагне зменшити емоційну напругу та відновити афективну рівновагу [14, с.3-28]. У такому контексті опановувальна поведінка розглядається як процес реагування на стрес. Цей підхід надає можливість розрізнення звичної поведінки людини та опановувальної поведінки, але таке розуміння останньої звужується лише до реакції на стрес, а за умови його відсутності поведінка людини не тлумачиться як спроба опанування складних життєвих ситуацій та труднощів [15].

Третій підхід трактування копінгу представлений у роботах Р. Лазаруса та С. Фолкмана. Дослідники під копінгом розуміють динамічний процес, який здатний до самовидозмінення та визначається суб’єктивними переживаннями 
ситуації особистістю. Науковці під психологічним подоланням розуміли когнітивні та поведінкові зусилля людини, які спрямовані на зменшення впливу стресових ситуацій [16]. Розглядаючи копінг-поведінку, автори виокремлювали іiі активну та пасивну форми прояву. До активної форми відносять цілеспрямовані зусилля людини 3 метою усунення або послаблення впливу стресових ситуацій, а пасивною формою $\epsilon$ використання механізмів психологічного захисту. Р. Лазарус робив акцент на тому, що способи реагування людини на складні життєві ситуації обумовлюються іiі суб'єктивною оцінкою складної життєвої ситуації та можливостей ऑiі усунення або подолання [17]. Когнітивну оцінку Р. Лазаруста С. Фолкман поділяють на первинну та вторинну. Первинна когнітивна оцінка передбачає сприймання людиною складної (стресогенної) ситуації та визначається особистісними чинниками, які дають можливість оцінити інформацію стосовно таких ситуацій. Вторинна оцінка виступає доповненням первинної та відповідає за визначення засобів, якими людина може вплинути на складну життєву ситуацію. Загалом когнітивна оцінка складних ситуацій обумовлює активізацію особистістю копінг-стратегій, тобто дій, які спрямовані на зменшення та усунення тривоги, емоційно-негативних станів.

Незважаючи на низку різних підходів до вивчення опановувальної поведінки, більшість них грунтуються саме на дослідженнях Р. Лазаруса та C. Фолкмана. Узагальнюючи погляди науковців X. Кроне наводить ряд особливостей опановувальної поведінки (копінгу). По-перше, копінг-дії не класифікуються відповідно до їхніх наслідків, а за певними характеристиками процесу подолання, що призводить до певного ототожнення копінг-дій та копінгстратегій. По-друге, цей процес включає в себе поведінкові та когнітивні реакції людини. По-третє, у більшості випадків копінг складається 3 різних окремих, послідовно організованих актів, що утворюють епізод копінгу. По-четверте, копінг-стратегії поділяються на проблемно-орієнтовані, тобто ті, які спрямовані на зміну стресової транзакції людини з навколишнім середовищем та емоційноорієнтовані, які спрямовані на зменшення емоційного напруження або зміну оцінки складної ситуації [18].

Серед вітчизняних дослідників велика кількість робіт також присвячена вивченню копінгу. Зазвичай дослідження копінгу українськими вченими спрямоване на емпіричне визначення певних його особливостей відповідно індивідуально-психологічних, професійних або соціально-демографічних характеристик. Комплексно розгляд копінг-поведінки представлено у роботах Н. Родіної. Так на думку дослідниці, копінг виступає структурною «надбудовою» особистості, яку вона може усвідомити та виникає ця «надбудова» у результаті соціалізації як наслідок взаємодії несвідомих мотивів людини та несприятливих факторів навколишнього середовища. Копінг-стратегії, як зазначає Н. Родіна виступають усвідомленими діями особистості, а психологічні захисти $\epsilon$ «первинними та асоціюються 3 глибинною несвідомою площиною подолання конфлікту» [19, с.87]. 
На важливості дослідження опановувальної поведінки наголошує також Л. П'янківська. Дослідниця зазначає, що несформованість копінг-стратегій поведінки спричиняє порушення соціальної взаємодії, деструктивні зміни особистості, детермінує проблеми адаптації та саморозвитку. Копінг-стратегії, на думку Л. П'янківської, $є$ важливими не тільки для особистості, але й для

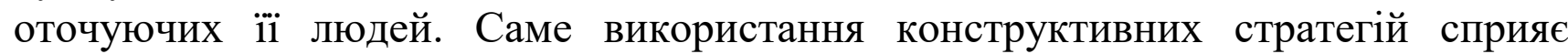
згуртуванню, покращенню взаємин, взаємопідтримці та довірі. Також, як зауважує дослідниця, у майбутньому використання переважно неконструктивних копінг-стратегій може призводити до маніпулятивних дій, зниженню стресостійкості і загалом негативно впливати на здоров'я особистості. Тому виникає потреба у навчанні людей використовувати активний копінг, який орієнтований на вирішення стресових ситуацій. Підсумовуючи свої дослідження Л. П'янківська зазначає, що конструктивні копінг-стратегії допомагають особистості підвищити задоволеність життя, розширити зону комфорту, невілювати почуття безпорадності, а складні життєві ситуації сприймати як можливість самореалізації [20, с.184-185].

Незважаючи на велику кількість наявних досліджень опановувальної поведінки, досліджень які б розкривали взаємозв'язок опанування та моральної сфери досить мало. Наше дослідження спрямоване на визначення особливостей опанувальної поведінки осіб з різними типами моральної свідомості. Моральна свідомість виступає регулятором поведінки, а тому має вплив на процес опанування особистістю складних життєвих ситуацій.

Так, російський вчений Р. Ветров досліджуючи моральні ресурси подолання особистістю кризових ситуацій наголошує, що «моральна складова поведінки особистості має складну детермінацію: на відносність норм впливають культурно-історичні особливості суспільства в цілому, а також соціальногрупова специфіка і умови середовища» [21, с.147]. В межах однієї групи ставлення до однакових моральних норм може змінюватися в залежності від ситуаційного контексту: так норми в умовах змагання інші, ніж в умовах співробітництва. Моральні регулятори несуть в собі когнітивне і афективне забарвлення, але все-таки визначаються, перш за все, як поведінковий компонент взаємодії.

Серед українських дослідників взаємозв'язок опановувальної поведінки та моральних якостей досліджувалися О. Никоненко. Дослідження проводилося у фокусі духовної парадигми психології, де одним із основних ендофакторів формування моральних якостей особистості виступала совість. Однією з гіпотез цього дослідження виступало те, що особи з високим рівнем розвитку моральних якостей обирають конструктивні стратегії поведінки в стресових ситуаціях, а 3 низьким рівнем - неконструктивні. В результаті було виявлено, що особам 3 високим рівнем розвитку моральних якостей притаманний вибір конструктивних способів поведінки в стресових ситуаціях. Тобто їм властиві самоконтроль, прийняття відповідальності, планування рішення проблеми. Для осіб з низьким 
Журнал«Герспективитаінноваціїнауки

(Серія«Гедагогіка», Серія«Гцихологія», Серія«Медицинв»

№4(4) 2021

рівнем розвитку моральних якостей більш характерним $\epsilon$ використання неконструктивних поведінкових стратегій в цих ситуаціях - конфронтація, дистанціювання, уникнення дійсності [22].

Загалом аналізуючи різні погляди щодо механізмів психологічного захисту та копінг-стратегій можна зробити висновок, що перші функціонують поза межами свідомості людини, тоді як другі є усвідомленими процесами, які можуть піддаватися контролю. Саме тому, ми можемо говорити про те, що опановувальна поведінка буде відображати характерні відмінності між людьми в умовах складних життєвих ситуацій.

Висновки. Аналіз наукових поглядів щодо опановувальної поведінки показав, що однозначного розуміння цього феномену немає. Водночас більшість науковців вбачають доцільним досліджувати механізми психологічного захисту та копінг-стратегій у тісній взаємодії. Узв'язку з тим, що практично всі люди в певний період життя переживають складні життєві ситуації, проблема опановувальної поведінки не втрачає своєї актуальності. Перспективи подальших розвідок вбачаємо у дослідженні особливостей опанувальної поведінки осіб з різними типами моральної свідомості тому, що це розширить спектр наявних досліджень взаємозв'язку опанування складними ситуаціями 3 моральною сферою особистості для подальшого практичного застосування.

\section{Лimepamypa:}

1. Фрейд А. Эго и механизмы защиты. / А. Фрейд. - Москва: ООО Апрель-Пресс; ЗАО Изд-во ЭКСМО-Пресс, 1999. - 160 с.

2. Хорни К. Невротическая личность нашего времени. Самоанализ. / К. Хорни Москва: Прогресс, 1993. - 188 с.

3. Бассин Ф. В. Проблема бессознательного. / Ф. Бассин. - Москва: Медицина, 1968. - 468 с.

4. Налчаджян А. А. Социально-психическая адаптация (формы, механизмы и стратегии). / А. А. Налчаджян. - Ереван: Изд-во АН Арм ССР, 1988. - 263с.

5. Василюк Ф. Е. Психология переживания: анализ преодоления критических ситуацій./ Ф. Е. Василюк. - Москва: МГУ, 1984. - 200 с.

6. Даценко Т. О. Ресурси особистості, спрямовані на подолання страху: психологічний захист і копінг-стратегії / Т. О. Даценко // Теоретичні і прикладні проблеми психології. - 2014. - №3. $-150-155$.

7. Plutchik, R. (2000). Emotions in the practice of psychotherapy: Clinical implications of affect theories. American Psychological Association. https://doi.org/10.1037/10366-000

8. Никольская, И. М., Грановская, Р. М. Психологическая защита у детей. / И. М. Никольская, Р. М. Грановская. - Санкт-Петербург: Речь, 2006. - 342 с. Тітаренко, Д.С. (2009). Захисні механізми психіки людини. Проблеми екстремальної та кризової психологї, (6), 182-192.

9. Тітаренко Д.С. Особливості функціонування механізмів психологічного захисту у рятувальників в умовах екзистенціальної загрози: Монографія. / О.А. Олійников, Н.В. Оніщенко, О.В. Тімченко, Д.С. Тітаренко, В.С. Христенко - Х.: НУЦЗУ, 2011. - 151 с.

10. Тітаренко Д.С. Захисні механізми психіки людини / Д.С. Тітаренко // Проблеми екстремальної та кризової психології. Збірник наукових праць. Вип.6. - Харків: УЦЗУ, 2009. C. 181-191.

11. Lasarus R.S. (1966) Psychological stress and the coping process. New York. 
12. Haan N. (1977). Coping and defending: processes of environment organization. New York: Academic Press.

13. Грандт, В.В. (2012). Копінг-ресурси як чинник професійного здоров'я представників екстрених служб: вектори психологічної ефективності збереження професійної надійності. / В. В. Грандт // Проблеми сучасної психології. - 2012. - №1. - С. 97-102.

14. Moos R.H. (1986). Life transition and crises. New York: Plenum Press.

15. Корнієнко I.O. Стратегії копінг-поведінки студента в ситуації неуспіху : монографія/ І.О. Корнієнко. - Мукачево : Карпатська вежа, 2011. - 292 с.

16. Lazarus, R. S. (1993). From psychological stress to the emotions: A history of changing outlooks. Annual review of psychology, 44(1), 1-22.

17. Folkman, S., Lazarus, R. S., Dunkel-Schetter, C., DeLongis, A., \& Gruen, R. J. (1986). Dynamics of a stressful encounter: Cognitive appraisal, coping, and encounter outcomes. Journal of Personality and Social Psychology, 50(5), 992-1003. https://doi.org/10.1037/0022-3514.50.5.992

18. Krohne, H. W. (2002). Stress and coping theories. International Encyclopedia of the Social Behavioral Sceinces, 22, 15163-15170.

19. Родіна Н. Психологія копінг-поведінки: системне моделювання : дис. ... докт. психол. наук: 19.00.01. / Родіна Наталія Володимирівна. - Київ. нац. ун-т ім. Тараса Шевченка, 2012. $-504 \mathrm{c}$.

20. Пянківська, Л. В. Копінг-стратегії поведінки поліцейського. / Л. В. Пянківська // Тези доповідей Всеукр. наук.-практ. конф.(Харків, 5 квітня 2019 р.). - Харків: МВС України, Харків. нац. унт внутр. справ. С. 184-186.

21. Ветров Р.Ю. Нравственные ресурсы преодоления личностью кризисных ситуаций: дисс. ... докт. психол. наук: 19.00.01. / Ветров Роман Юрійович. - Москва: Университет Российской академии образования, 2012. - 358 с.

22. Никоненко, О. П. (2014). Копінг-стратегії у студентів з різним рівнем розвитку моральних якостей у фокусі духовної парадигми психології. Режим доступу: http://www.ndu.edu.ua/images/stories/2014/konf_psy/nykonenko_o_p.pdf

\section{References:}

1. Freid, A. (1999) Ego i mekhanizmy zashchity [Ego and defense mechanisms]. Moskva: OOO Aprel-Press; ZAO Izd-vo EKSMO-Press. [In Russian].

2. Khorni, K. (1993). Nevroticheskaia lichnost nashego vremeni. Samoanaliz [The neurotic personality of our time. Introspection]. Moskva: Progress. [In Russian].

3. Bassin, F.V. (1968). Problema bessoznatelnogo [The problem of the unconscious]. Moskva: Meditcina. [In Russian].

4. Nalchadzhian, A.A. (1988). Sotcialno-psikhicheskaia adaptatciia (formy, mekhanizmy $i$ strategii) [Socio-mental adaptation (forms, mechanisms and strategies)]. Erevan: Izd-vo AN Arm SSR. [In Russian].

5. Vasiliuk, F.E. (1984). Psikhologiia perezhivaniia: analiz preodoleniia kriticheskikh situatcii [Psychology of experience: analysis of overcoming critical situations]. Moskva: MGU. [In Russian].

6. Dacenko, T. O. (2014). Resursy osobystosti, sprjamovani na podolannja strahu: psyhologichnyj zahyst i koping-strategii' [Resource of specialness, directing to the side of fear: psychology and copying strategy.]. Teoretychni i prykladni problemy psyhologii' [Theoretical and applied problems of psychology], (3), 150-155. [in Ukrainian].

7. Plutchik, R. (2000). Emotions in the practice of psychotherapy: Clinical implications of affect theories. American Psychological Association. https://doi.org/10.1037/10366-000

8. Nikolskaia, I. M., Granovskaia, R. M. (2006). Psikhologicheskaia zashchita u detei [Psychological protection in children]. Sankt-Peterburg: Rech. [In Russian]. 
9. Olijnykov, O.A., Onishhenko, N.V., Timchenko, O.V., Titarenko, D.S., Hrystenko V.Je. (2011). Osoblyvosti funkcionuvannja mehanizmiv psyhologichnogo zahystu u rjatuval'nykiv v umovah ekzystencial'noi' zagrozy: monografija [Peculiarities of functioning of mechanisms of psychological protection at rescuers in the conditions of existential threat: monograph]. Harkiv: NUCZU. [in Ukrainian].

10. Titarenko, D.S. (2009). Zahysni mehanizmy psyhiky ljudyny [Protective mechanisms of the human psyche]. Problemy ekstremal'noi' ta kryzovoi' psyhologii' [Problems of extreme and crisis psychology], (6), 182-191. [in Ukrainian].

11. Lasarus R.S. (1966) Psychological stress and the coping process. New York.

12. Haan N. (1977). Coping and defending: processes of environment organization. New York: Academic Press.

13. Grandt, V.V. (2012). Koping-resursy jak chynnyk profesijnogo zdorov'ja predstavnykiv ekstrenyh sluzhb: vektory psyhologichnoi' efektyvnosti zberezhennja profesijnoi' nadijnosti [Copyresources as an official of professional health of representatives of emergency services: vectors of psychological efficiency of protecting professional hopes.]. Problemy suchasnoi' psyhologii' [Problems of modern psychology], 1, 97-102 [in Ukrainian].

14. Moos R.H. (1986). Life transition and crises. New York: Plenum Press.

15. Kornijenko, I.O. (2011) Strategii' koping-povedinky studenta v sytuacii' neuspihu: monografija [Strategies for student coping behavior in a situation of failure: monograph]. Mukachevo: Karpats'ka vezha. [in Ukrainian].

16. Lazarus, R. S. (1993). From psychological stress to the emotions: A history of changing outlooks. Annual review of psychology, 44(1), 1-22.

17. Folkman, S., Lazarus, R. S., Dunkel-Schetter, C., DeLongis, A., \& Gruen, R. J. (1986). Dynamics of a stressful encounter: Cognitive appraisal, coping, and encounter outcomes. Journal of Personality and Social Psychology, 50(5), 992-1003. https://doi.org/10.1037/0022-3514.50.5.992

18. Krohne, H. W. (2002). Stress and coping theories. International Encyclopedia of the Social Behavioral Sceinces, 22, 15163-15170.

19. Rodina, N.V. (2012). Psyhologijakoping-povedinky: systemne modeljuvannja [Psychology of coping behavior: system modeling]. (Dys. dokt. psyhol. nauk). Kyi'vs'kyj nacional'nyj universytet imeni Tarasa Shevchenka [Taras Shevchenko National University], Kyi'v

20. Pjankivs'ka, L. V. (2019). Koping-strategii' povedinky policejs'kogo [Coping strategies of police behavior]. Vseukr. nauk.-prakt. konf.(Harkiv, 5 kvitnja 2019 r.) Harkiv: MVS Ukrai'ny, Harkiv. nac. unt vnutr. sprav. [in Ukrainian].

21. Vetrov, R.Iu. (2012). Nravstvennye resursy preodoleniia lichnostiu krizisnykh situatcii [Moral resources for overcoming crisis situations by a person.]. (Dis. Doktora psikhol. nauk). Universitet Rossiiskoi akademii obrazovaniia [University of the Russian Academy of Education], Moskva. [In Russian].

22. Nykonenko, O. P. (2014). Koping-strategii' u studentiv $\mathrm{z}$ riznym rivnem rozvytku moral'nyh jakostej u fokusi duhovnoi' paradygmy psyhologii' [Coping strategies for students with different levels of development of moral qualities in the focus of the spiritual paradigm of psychology]. Retrieved from http://www.ndu.edu.ua/images/stories/2014/konf_psy/nykonenko_o_ p.pdf [in Ukrainian]. 